\title{
Effect of Pressure and Temperature Change on Undersaturated Oil Viscosity
}

\author{
Mohammed M. Daway \\ Petroleum Engineering Department, College of Engineering, University of Baghdad
}

\section{Abstract:}

A study has been done based on data received from one of the southern Iraqi's oil fields, consists of eighty eight experimental points of oil viscosity at known pressure and temperature above the bubble point pressure.

Fourteen formulas assumed to define the effect of pressure and temperature change on undersaturated oil viscosity. Every formula gives a value of viscosity at any temperature and pressure (above bubble point) depending on a known value of

viscosity at known pressure and temperature. Depending on the least squares method, the constants of these formulas are calculated.

A formula appeared to have the minimum average absolute error (4.8 $\%)$ with a value of correlation coefficient equal to (0.8996) is selected to be the best formula adopted in this study. The most proper formula has been compared with two correlations (Khan's correlation and Vasquez and Beggs correlation) and it appeared to be better than the both correlations.

الدراسة اعتمدت على بيانات مأخوذة من أحد

حقول النفط العراقية، تتضمن ثمانية وثمانون قيمة للزوجة عند قيم معلومة من ضغط ودرجة حرارة (فوق ضغط نقطة الفقاعة).

تم إفتراض 14 صيغة لتحديد تأثير تغير الضغط ودرجة الحرارة على لزوجة النفط غير المشبع. كل صيغة من هذه الصيغ تعطي قيمة لزوجة عند أي ضغط ودرجة حرارة معلومين (فوق ضغط نقطة الفقاعة) إعتماداً على قيمة معلومة للزوجة عند ضغط ودرجة حرارة معلومين.

تم حساب الثوابت الخاصة بكل صيغة بطريقة المربعات الصغرى. إحدى الصيغ ظهر لها أقل نسبة خطأ (4,8 \% مع قيمة معامل إرتباط تساوي (0,8996)، تم إختيارها لتكون الصيغة المقترحة في هذه الدراسة. تم مقارنة الصيغة التي تم الحصول عليها مع علاقنين عالميتين (علاقة خان وعلاقة فازكيز وبيكز)، وقد ظهر لنا إنها أفضل من كلتا العلاقتني. 


\section{Introduction:}

The viscosity of crude oil with dissolved gas is an important parameter in pressure-drop calculations for flow in pipes or in porous media. Whenever possible, the oil viscosity should be determined in the laboratory for the required pressure and temperature ranges (1).

Depending on the pressure, the viscosity of crude oils can be classified into three categories (2):

1.Dead oil viscosity, $\mu_{\mathrm{od}}$. The dead oil viscosity (oil with no gas in the solution) is defined as the viscosity of crude oil at atmospheric pressure and system temperature, $\mathrm{T}$.

2. Saturated oil viscosity, $\mu_{\mathrm{ob}}$. The saturated (bubble-point) oil viscosity is defined as the viscosity of the crude oil at any pressure less than or equal to the bubble-point pressure.

3. Undersaturated oil viscosity, $\mu_{\mathrm{o}}$. The undersaturated oil viscosity is defined as the viscosity of the crude oil at a pressure above the bubblepoint and reservoir temperature.

There are several empirical correlations used to calculate the oil viscosity based on frequently available hydrocarbon system parameters, such as temperature, pressure, oil gravity, gas gravity, and gas solubility.

Models can be classified into three different categories:

1- Theoretical models,

2- Semi-theoretical models,

\section{3- Empirical models.}

The theoretical models are mainly used for calculating viscosities of pure component and their mixtures. Empirical models are mainly described in terms of correlations. The two main types of empirical models are Andrade (3), and ASTM (ASTM 1981) (4). Semi theoretical models for viscosity prediction have provided blend between theoretical and correlative models. These models include formulas based on corresponding states theory, reaction rate theory, hard sphere theory, as well as the square well model, Lennard-Jones models, and modified Chapman-Enskog model (5).

The present work is a study of the effect of pressure and temperature on undersaturated oil viscosity. The viscosity of crude oil with dissolved gas is an important parameter used in calculations of flow in pipes or in porous media.

A project of Petroleum Development Laboratory in 2008 (5) focused on predicting phase behavior and viscosity of viscous oils using equations of state and semi-empirical correlations. An experimental study was conducted to quantify the phase behavior and physical properties of viscous oils from the Alaska North Slope oil field. 
The widely used corresponding state viscosity model predictions deteriorate when applied to heavy oil systems. Hence, a semi-empirical approach (Lindeloff model) ${ }^{(6)}$ was adopted for modeling the viscosity behavior. Based on the analysis, appropriate adjustments have been suggested: the major one is the division of the pressure-viscosity profile into three distinct regions.

In a volume translation for the Peng-Robinson cubic equation of state was presented in 2009 for a better description of densities[7] . it was expressed that the viscosity model has been developed based on the similarity between PVT and T $\mu \mathrm{P}$ relationship. Also it was mentioned that the viscosity model can also describe the relation of the saturated vapor pressure with temperature.

\section{Dead-Oil Viscosity Correlations:}

For empirical correlations, the deadoil viscosity is determined first. The dead oil is defined at atmospheric pressure and at any fixed system temperature without dissolved gas. This dead-oil viscosity then is corrected for the system pressure condition. Normally dead-oil viscosity is determined in the laboratory whenever PVT analysis is done (1).

\section{Beal's Correlation:}

A graphical correlation (Fig. 1) was presented to determine dead-oil viscosity if the API gravity of the crude oil and the temperature are known[8]. The following mathematical equation to represent Beal's correlation was presented for dead-oil viscosity $\left(\mu_{o d}\right)$ at 1 atm pressure and temperature, $\mathrm{T}$, in ${ }^{\circ} \mathrm{R}(\mathrm{a})$.

$$
\mu_{o d}=\left(0.32+\frac{1.8 \times 10^{7}}{\gamma_{\mathrm{API}}{ }^{4.53}}\right)\left(\frac{360}{T-260}\right)^{a}
$$

Where:

$$
a=10^{\left(0.43+8.33 / \gamma_{\mathrm{API}}\right)}
$$

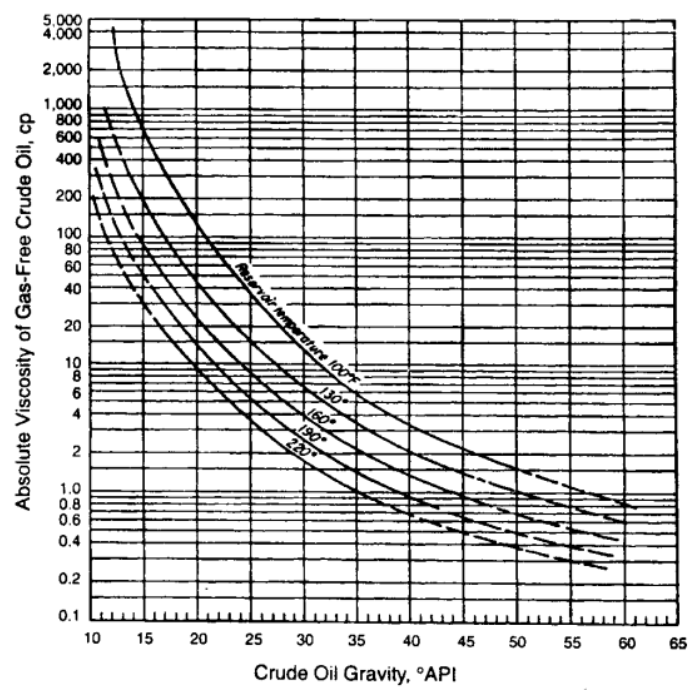

Fig. (1) Gas free viscosity as a function of temperature and oil gravity at $60^{\circ} \mathrm{F}$ and atmospheric pressure ${ }^{(8)}$. 


\section{Beggs and Robinson Correlation:}

a different empirical correlation was propose to determine the dead-oil viscosity[10] . It is based on 460 deadoil viscosity measurements and can be expressed as:

$\mu_{o d}=10^{x}-1$

Where:

$$
x=\frac{10^{\left(3.0324-0.02023 \gamma_{\mathrm{API}}\right)}}{T^{1.163}}
$$

Kartoatmodjo and Schmidt's

\section{Correlation:}

In its empirical form, this correlation (11) is a combination of the above three correlations; they are Beal's correlation (8), Standing's correlation (9) and Beggs and Robinson's correlation (10), it can be expressed as: $\left.\mu_{\text {od }}=\left(16.0 \times 10^{8}\right) T^{-2.8177\left(\log \gamma_{\text {AP }}\right)}\right)^{5.7526 \log (T)-26.9718 .}$.

\section{Saturated Crude Oil Viscosity:}

The reservoir oil viscosity depends on the solution-gas content. Oil viscosity decreases with rising pressure as the solution gas increases, up to the bubble point pressure. There are few empirical correlations to determine the viscosity of saturated or under saturated crude oil systems.

\section{Beggs and Robinson Correlation:}

This correlation (10) is based on 2,073 saturated oil viscosity measurements. The empirical form of this equation is:

$$
\mu_{o}=\left[10.715\left(R_{s}+100\right)^{-0.515}\right] \mu_{o d}^{b}
$$

Where:

$b=5.44\left(R_{s}+150\right)^{-0.338}$

This correlation was developed from these ranges of data:

Pressure $=132$ to 5,265 psia,

temperature $=70$ to $295^{\circ} \mathrm{F}$,

oil gravity $=16$ to $58^{\circ} \mathrm{API}$,

and gas solubility $=20$ to 2,070 scf/STB.

\section{Kartoatmodjo and Schmidt's Correlation:}

This correlation (11) recommends the following correction of the dead-oil viscosity presented in equation bellow to determine the live-oil viscosity, $\mu_{0}$,

$$
\mu_{o}=-0.06821+0.9824 f+0.0004034 f^{2}
$$

Where:

$$
f=\left(0.2001+0.8428 \times 10^{\left.-0.000845 S_{s}\right)}\right) \mu_{o d}^{(0.43+0.51655)}
$$

and

$$
y=10^{-0.0008 R_{s}}
$$




\section{Undersaturated Crude Oil Viscosity:}

Above the bubble-point pressure, rising pressure increases the viscosity of oil because of its compressibility; that is when the pressure increases then the oil molecules become closer from each other and then the internal friction of oil increases, so the viscosity increases because it is a measure of the internal friction.

\section{Khan's Correlation:}

From 1500 experimental viscosity data points on Saudi Arabian crude oil systems, The following equation was developed with a reported absolute average relative error of $2 \%$ [12]:

$$
\mu_{o}=\mu_{o b} \exp \left[9.6\left(10^{-6}\right)\left(p-p_{b}\right)\right]
$$

\section{Vasquez and Beggs's Correlation:}

The following correlation was proposed to determine crude oil viscosity above the bubble point pressure using the viscosity at the bubble point pressure for pressures[13].

$$
\mu_{o}=\mu_{o b}\left(\frac{p}{p_{b}}\right)^{m}
$$

Where:

$$
m=2.6 p^{1.187} 10^{a}
$$

and

$$
a=-\left(3.9 \times 10^{-5}\right) p-5
$$

This correlation is based on data in the following ranges:

Pressure $=141$ to 9,515 psia,

Gas solubility $=90.3$ to 2,199 scf/STBO,

Viscosity $=0.117$ to $148 \mathrm{cp}$,

Gas specific gravity $=0.511$ to 1.351 ,

and oil gravity $=15.3$ to $59.5^{\circ} \mathrm{API}$.

Kartoatmodjo and Schmidt's Correlation:

This correlation (11) allows correction of the saturated crude oil viscosity at the bubble-point, $\mu_{\mathrm{ob}}$, based on equation (8) for undersaturated pressure, $p$.

$$
\begin{array}{r}
\mu_{o}=1.00081 \mu_{o b}+0.001127\left(p-p_{b}\right) \\
\times\left(-0.006517 \mu_{o b}^{1.8148}+0.038 \mu_{o b}^{1.590}\right)
\end{array}
$$

\section{Data of the project:}

The data studied in this project were obtained from one of the south Iraqi oil fields. The data represents 88 experimental points of the viscosity with temperature and pressure (above bubble point), with other fluid properties values such as: API gravity, formation volume factor, gas oil ratio ... etc. A sample of these data is listed in Table (1). 
Table (1) Sample of data received from one of the south Iraqi oil fields

\begin{tabular}{|c|c|c|c|c|c|c|c|}
\hline Well & $\mathbf{T}\left({ }^{0} \mathbf{F}\right)$ & $\bar{P}(\mathbf{p s i})$ & Viscosity (cp) & Well & $\mathbf{T}\left({ }^{0} \mathbf{F}\right)$ & $\overline{\mathbf{P} \text { (psi) }}$ & Viscosity (cp) \\
\hline \multirow[t]{6}{*}{ A-1 } & 159.98 & 5000 & 1.128 & \multirow[t]{6}{*}{ A-3 } & 177.98 & 5000 & 1.081 \\
\hline & 159.98 & 4500 & 1.053 & & 177.98 & 4500 & 1.005 \\
\hline & 159.98 & 4000 & 0.993 & & 177.98 & 4000 & 0.939 \\
\hline & 159.98 & 3500 & 0.935 & & 177.98 & 3500 & 0.905 \\
\hline & 159.98 & 3000 & 0.875 & & 177.98 & 3000 & 0.86 \\
\hline & 159.98 & 2500 & 0.836 & & 177.98 & 2500 & 0.83 \\
\hline \multirow[t]{5}{*}{ A-2 } & 172.04 & 4500 & 1.03 & \multirow[t]{5}{*}{ A-4 } & 159.8 & 5000 & 1.171 \\
\hline & 172.04 & 4000 & 0.99 & & 159.8 & 4500 & 1.092 \\
\hline & 172.04 & 3500 & 0.96 & & 159.8 & 4000 & 1.033 \\
\hline & 172.04 & 3000 & 0.92 & & 159.8 & 3500 & 0.985 \\
\hline & 172.04 & 2500 & 0.88 & & 159.8 & 3000 & 0.936 \\
\hline
\end{tabular}

The range of these data is as follows:

Pressure $=1907$ to 5000 psia,

Oil formation volume factor $=1.022$ to $1.408 \mathrm{RB} / \mathrm{STB}$,

Undersaturated oil Viscosity $=0.725$ to $1.276 \mathrm{cp}$,

Solution gas oil ratio $=564$ to 705 $\mathrm{scf} / \mathrm{STB}$,

Gas specific gravity $=0.511$ to 1.351 , and oil specific gravity $=0.739$ to 0.777 .

\section{Method of calculations:}

In order to get an appropriate formula, fourteen different formulas are assumed first, and then the constants of these formulas are calculated using least squares method. Other values of oil viscosity are calculated $\left(\mu_{c}\right)$ using the assumed formulas. Then the average absolute error (AAE) is calculated from the following formula:

$$
A A E=\frac{1}{n} \sum_{i=1}^{n}\left|\frac{\mu_{c i}-\mu_{a i}}{\mu_{a i}}\right|
$$

All the calculations were done and programmed using MATLAB programmming language.

\section{The Results:}

Fourteen formulas were used in this work. Table (2) represents the results of formulas with the constants of each formula, and the average absolute error for each formula (output of the program): 
Table (2) Results of calculations: Formulas assumed with constants and average absolute error

\begin{tabular}{|c|c|c|c|c|c|c|}
\hline \multirow{2}{*}{ Formula } & \multicolumn{5}{|c|}{ Constants } & \multirow{2}{*}{ AAE, \% } \\
\hline & $\mathbf{a}$ & $\mathbf{B}$ & c & d & $\mathbf{e}$ & \\
\hline$\Delta \mu=a \Delta P+b \Delta T$ & $9.44 \mathrm{E}-05$ & -0.0057 & ----- & ---- & ----- & 4.878022 \\
\hline$\Delta \mu=a \Delta(P T)+b \Delta P+c \Delta T$ & $-3.7 \mathrm{E}-07$ & 0.00016 & -0.00434 & ---- & $-\mathbf{c}^{----}$ & 4.874146 \\
\hline$\Delta \mu=a \Delta\left(P T^{2}\right)+b \Delta(P T)+c \Delta P+d \Delta T$ & $-8.1 \mathrm{E}-09$ & $2.5 \mathrm{E}-06$ & $-8.8 \mathrm{E}-05$ & -0.00467 & ----- & 4.819781 \\
\hline$\Delta \mu=a \Delta\left(P^{2} T\right)+b \Delta(P T)+c \Delta P+d \Delta T$ & $3.16 \mathrm{E}-14$ & $-9 \mathrm{E}-11$ & $9.4 \mathrm{E}-05$ & -0.00572 & ---- & 4.877976 \\
\hline$\Delta \mu=a \Delta P^{2} T+b \Delta P T^{2}+c \Delta P T+d \Delta P+e \Delta T$ & $-1 \mathrm{E}-14$ & $-1 \mathrm{E}-09$ & $4.6 \mathrm{E}-10$ & 0.00014 & $-4.6 \mathrm{E}-16$ & 4.862139 \\
\hline$\Delta \mu=a \Delta\left(P^{2} T^{2}\right)+b \Delta(P T)+c \Delta P+d \Delta T$ & $-4.6 \mathrm{E}-16$ & $5.4 \mathrm{E}-07$ & 8.4E-08 & -0.00774 & ----- & 4.99204 \\
\hline$\Delta \mu=a \Delta(1 / p)+b \Delta(1 / T)$ & -1157.69 & 162.707 & ---- & $\begin{array}{ll}--- \\
---\end{array}$ & $\begin{array}{ll}---- \\
---\end{array}$ & 5.425675 \\
\hline$\Delta \mu=a \Delta(P / T)+b \Delta(T / P)$ & 0.030626 & 5.79057 & ----- & ----- & ----- & 6.219013 \\
\hline$\Delta \mu=a \Delta(1 / P)+b \Delta(P / T)$ & 1519.378 & 0.03581 & -0.25648 & $\begin{array}{ll}---- \\
---\end{array}$ & $\begin{array}{l}---- \\
---\end{array}$ & 5.158282 \\
\hline$\Delta \mu=a \Delta(1 / p)+b \Delta(P / T)+c \Delta P$ & 1077.014 & 0.03908 & $-5.4 \mathrm{E}-05$ & ----- & ----- & 5.042206 \\
\hline$\Delta \mu=a \Delta P^{2}+b \Delta T$ & $1.23 \mathrm{E}-08$ & -0.0056 & ----- & ----- & ----- & 4.823904 \\
\hline$\mu=\mu_{k} \exp (a \Delta(P T))$ & $2.1 \mathrm{E}-07$ & $\begin{array}{ll}---- \\
---\end{array}$ & ---- & $\begin{array}{ll}--- \\
---\end{array}$ & $\begin{array}{ll}--- \\
---\end{array}$ & 9.542131 \\
\hline$\mu=\mu_{k} \exp (a \Delta(P / T))$ & 0.01882 & $\begin{array}{ll}--- \\
---\end{array}$ & $\begin{array}{ll}--- \\
---\end{array}$ & $\begin{array}{ll}--- \\
---\end{array}$ & $\begin{array}{ll}--- \\
---\end{array}$ & 6.399718 \\
\hline$\Delta \mu=a \Delta\left(P T^{2}\right)+b \Delta P+c \Delta T$ & $-7.3 \mathrm{E}-09$ & 0.00031 & 0.00358 & ---- & ---- & 5.228558 \\
\hline
\end{tabular}

\section{Comparison with the past corre-} lations:

The selected formula (having minimum AAE) is:

$$
\Delta \mu=a \Delta\left(P T^{2}\right)+b \Delta(P T)+c \Delta P+d \Delta T
$$

The above formula (appeared to have an AAE of $4.8198 \%$ and a correlation coefficient of 0.8996) was compared with two correlations; they are Khan's correlation and Vasquez and Beggs correlation.
In order to calculate undersaturated oil viscosity using any of the two correlations, there is a need to determine the oil viscosity at bubble point pressure $\left(\mu_{o b}\right)$ first.

Two methods have been used to determine $\left(\mu_{o b}\right)$. In the first method the correlations surveyed is used to calculate $\left(\mu_{o b}\right)$, while in the second method the actual value of the viscosity at bubble point pressure is used to determine $\left(\mu_{o b}\right)$. 
When using the actual value method, Khan's correlation and Vasquez and Beggs correlation appeared to have less AAE than the correlations method.

Khan's correlation appeared to have AAE equal to $53.6 \%$ using correlation method and $10.9 \%$ using the actual value method, while Vasquez and Beggs correlations showed an AAE value of $41.1 \%$ using correlations method and $5.55 \%$ using the actual value method.

The table below shows a comparison of the formula resulted from this study, Khan's correlation and Vasquez and Beggs correlation in calculation of undersaturated oil viscosity using four comparison criteria, they are: average absolute error, some of squared residuals, standard deviation, variance and correlation coefficient.

Table 3: Comparison of the results

\begin{tabular}{|l|c|c|c|c|}
\hline Correlation & $\begin{array}{c}\text { AAE, } \\
\%\end{array}$ & $\begin{array}{c}\text { Sum of Squared } \\
\text { residuals }\end{array}$ & Variance & $\begin{array}{c}\text { Standard } \\
\text { Deviation }\end{array}$ \\
\hline Proposed & 4.8198 & 0.228452 & 0.011139 & 0.10554 \\
\hline Khan & 10.916 & 1.611037 & 0.016865 & 0.129864 \\
\hline $\begin{array}{l}\text { Vasquez and } \\
\text { Beggs }\end{array}$ & 5.551 & 0.394272 & 0.022197 & 0.148987 \\
\hline
\end{tabular}

From the above table, it is clear that the proposed formula is better than the other two methods.

From the specification of the proposed correlation, that it can be applied for any oil by knowing one value of viscosity at known pressure and temperature. While the other

correlations need to know many parameters such as: API gravity, solution gas oil ratio, bubble point pressure, temperature ... etc.

\section{Conclusions:}

1. Based on data from one of the south Iraqi's oil fields, fourteen formulas
2. to define the effect of change of pressure and temperature on undersaturated oil viscosity, are assumed and the formula (eq. 17) appeared to be the best formula (among the assumed formulas) giving the minimum average absolute error.

3. From any known viscosity at known pressure (at or above bubble point pressure) and temperature; anyone can get the undersaturated oil viscosity at any pressure and temperature using this equation.

4. The proposed formula compared with two global correlations, and appeared to be better than both correlations according to the tested data. 


\section{Nomenclature:}

a : Variable defined in equations (2) and (14).

AAE : Average absolute error.

b : Variable defined in equation (7).

f : Variable defined in equation (9).

m : Variable defined in equation (13).

P : Pressure, psi.

$\mathrm{P}_{\mathrm{b}} \quad$ : Bubble point pressure, psi.

$\mathrm{R}_{\mathrm{s}} \quad$ : gas solubility, scf/STB

$\mathrm{T}$ : Temperature, ${ }^{\circ} \mathrm{F}$.

x : Variable defined in equation (4).

y : Variable defined in equation (10).

$\gamma_{\text {API }}:$ American petroleum institute unit, API.

$\Delta \quad$ : The change in the values of any variable (i.e. final value - initial value).

$\mu \quad$ : Undersaturated oil viscosity, cp.

$\mu_{\mathrm{ai}} \quad$ : Actual viscosity of $\mathrm{i}^{\text {th }}$ case.

$\mu_{\mathrm{ci}} \quad$ : Calculated viscosity of $\mathrm{i}^{\text {th }}$ case.

$\mu_{\mathrm{k}} \quad$ : Known viscosity, cp.

$\mu_{\mathrm{o}} \quad$ : Oil viscosity, cp.

$\mu_{\mathrm{ob}}$ : Oil viscosity at bubble point pressure, cp.

$\mu_{\text {od }}$ : Dead oil viscosity, cp. 


\section{References:}

1. Brill, J. B., Mukherjee, H., "Multiphase Flow in Wells", first printing, Henry L. Doherty, memorial fund of AIME, Richardson, Texas, 1999.

2. Ahmed, T., "Equations of State and PVT Analysis: Applications for Improved Reservoir Modeling", Gulf Publishing Company, Houston, Texas, 2007.

3. Andrade, E. N., "Theory of Viscosity of Liquids.", Philosophical Magazine, vol. 17, pp. 497-511, 1934; ibid, vol. 17, pp. 698-732, 1934.

4. ASTM, Annual Book of ASTM Standards, Part 23, ASTM, Philadelphia, PA, 1981.

5. Chapman- Enskog, "Phase behavior, solid organic participation, and mobility characterization studies in support of Enhanced heavy oil recovery on the Alaska north slope" final report, petroleum dept. laboratory, Institute of Northern Engineering, University of Alaska fabricants, 2008.

6. Lindeloff, N., Pedersen, K. S., Rønningsen, H. P., and Milter, J., "The Corresponding States Viscosity Model Applied to Heavy Oil Systems", J. Can. Pet. Tech., vol. 43(9), pp. 47-53, 2004.

7. Li-Sheng Wang and Hui-Chao Lv, "A Unified Model for Representing Densities and Viscosities of Hydrocarbon Liquids and Gases Based on PengRobinson Equation of State", The Open Thermodynamics Journal, vol. 3, 2009.

8. Beal, C. "The Viscosity of Air, Water, Natural Gas, Crude Oils and Its Associated Gases at Oil Field Temperatures and Pressures", Trans., AIME (1946) 165, 94.

9. Standing, M.B.: Volumetric and Phase Behavior of Oil Field Hydrocarbon Systems, ninth edition, SPE, Richardson, Texas (1981).

10.Beggs, H.D. and Robinson, J.R.: "Estimating the Viscosity of Crude Oil Systems", JPT (September 1975) 1140.

11.Kartoatmodjo, T. and Schmidt, Z.: "New Correlations for Crude Oil Physical Properties", paper SPE 23556, Richardson, Texas (June 1991).

12.Khan, S., et al. "Viscosity Correlations for Saudi Arabia Oils", SPE Paper 15720. Dallas: Society of Petroleum Engineers, 1987.

13.Vasquez, M. and Beggs, H.D.: "Correlations for Fluid Physical Property Prediction", JPT (June 1980) 968; Trans., AIME, 269. 